\title{
Atmospheric Dynamics and Ozone Cycle during Sea Breeze in a Mediterranean Complex Urbanized Coastal Site $\mathscr{D}$
}

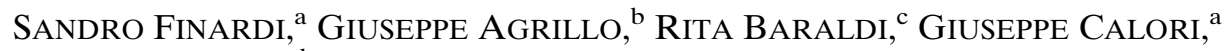 \\ Pantaleone CARlucci, ${ }^{\mathrm{b}}$ PAOlO Ciccioli,${ }^{\mathrm{c}}$ Alessio D'Allura, ${ }^{\mathrm{a}}$ DANiEle Gasbarra, \\ Beniamino Gioli, ${ }^{\mathrm{d}}$ Vincenzo Magliulo, ${ }^{\mathrm{b}}$ PaOla Radice, ${ }^{\mathrm{a}}$ Piero Toscano, ${ }^{\mathrm{d}}$ And \\ ALESSANDRO ZALDEI ${ }^{\mathrm{d}}$ \\ ${ }^{a}$ ARIANET S.R.L., Milan, Italy \\ ${ }^{\mathrm{b}} \mathrm{CNR} / \mathrm{ISAFOM}$, Ercolano, Italy \\ ${ }^{\mathrm{c}} \mathrm{CNR} / \mathrm{IBIMET}$, Bologna, Italy \\ ${ }^{\mathrm{d}}$ CNR/IBIMET, Florence, Italy \\ ${ }^{\mathrm{e}}$ Università di Napoli Federico II, Naples, Italy
}

(Manuscript received 3 May 2017, in final form 15 January 2018)

\begin{abstract}
Persistent high pressure conditions over the Mediterranean Basin favor the occurrence of sea breezes that can lead to ozone transport through complex recirculation patterns. These features were investigated during an ozone episode with hourly concentrations exceeding $200 \mu \mathrm{g} \mathrm{m}^{-3}$ that occurred on July 2015 in Naples (Italy), one of the largest and densest conurbations in the Mediterranean region. Aircraft measurements were taken at heights from 150 to $1500 \mathrm{~m}$ AGL and compared and integrated with high-resolution meteorological and air quality model simulations to investigate local circulation and pollutants dynamics. The integration of airborne measurements, surface observations, and modeling established a framework to assess the photochemical phenomena in the area. Sea breezes and local emissions triggered ozone production at inland areas, causing high concentrations between the coast and the Apennine chain. Ozone was then injected into the upper boundary layer and transported toward the sea by the wind rotation occurring above $500 \mathrm{~m}$ AGL, causing a complex vertical layering of concentrations, with maxima between 500 and $800 \mathrm{~m}$ AGL. Vertical growth of the ozone concentration profile was also caused by the decrease of the boundary layer depth occurring when the breeze front reached the inland area carrying $\mathrm{NO}_{x}$-rich air from the densely populated coast and favoring titration near the surface. Although the whole airshed was a net ozone producer, local surface concentrations were determined by a complex interaction of atmospheric flow and chemistry at different scales, supporting the need for coordinated efforts to control smog precursors over wide areas.
\end{abstract}

\section{Introduction}

Ozone is a photochemical air pollutant with harmful effects on humans, animals, and plants. Recent epidemiological studies showed that both long- and shortterm exposure to elevated ozone concentrations result in increased morbidity and mortality (WHO 2013; Henschel and Chan 2013). Ozone absorption damages plant cells, impairing their functionality and affecting agricultural yields and forest growth (Paoletti 2006;

Supplemental information related to this paper is available at the Journals Online website: https://doi.org/10.1175/JAMC-D-170117.s1.

Corresponding author: Sandro Finardi, s.finardi@aria-net.it
Calfapietra et al. 2009). Although ozone is a major indicator of photochemical smog itself, its production is connected to the abundance of other organic and inorganic reactive species potentially harmful for human beings and plants, being associated with an increase of the oxidative capacity of the atmosphere and secondary aerosol formation (Atkinson 2000; Kanakidou et al. 2005).

The vulnerability of the Mediterranean Basin to photochemical air pollution is well known; for example, Lelieveld et al. (2002) found summer ozone concentrations over the Mediterranean 2.5-3 times as high as the hemispheric background level. Satellite observations of tropospheric ozone highlight that the Mediterranean Basin is among the most noticeable production and accumulation zones at global scale (Ziemke et al. 2011). 
The analysis of long-term ozone measurements does not indicate a stable reduction trend for the photochemical pollution (Parrish et al. 2012; Sicard et al. 2013). The consistent reduction in anthropogenic precursors emissions achieved in the European Union has not led to the expected reduction in ozone concentrations (European Environment Agency 2015). Different factors contributed to this result: the increase in intercontinental transport of ozone and its precursors in the Northern Hemisphere, which drove an increase in hemispheric background concentrations (Bach et al. 2014); the reduction in emissions of nitrogen oxides $\left(\mathrm{NO}_{x}\right)$, which led to an increase in ozone concentrations inside highly urbanized areas because of the reduced titration effect (Sicard et al. 2013; Querol et al. 2014). Ozone therefore remains one of the pollutants of major concern in southern Europe. The potential health impact of ozone is particularly severe for large cities, where it combines with that of other air pollutants, and of the changing climate, as weather is expected to become increasingly warm and dry over the Mediterranean Basin in the next decades (IPCC 2007, 2014; Giorgi and Lionello 2008; Gualdi et al. 2013; Lionello et al. 2014).

Summertime atmospheric circulation in the western Mediterranean Basin is characterized by distinctive features: the presence of mountains close to coastal areas favors the combination of land-sea breezes, mountain-valley breezes, and slope winds, generating return flows possibly across several layers (Millán et al. 2000). Daytime compensatory subsidence over the coast and sea can be superimposed on large-scale subsidence because of the anticyclonic circulation over the basin. Nighttime land breeze can transport polluted air masses above the maritime boundary layer building reservoirs that may be advected onshore during the following day (Millán et al. 1997, 2000, 2002, 2005; Gangoiti et al. 2001; Ancellet and Ravetta 2005; Jiménez et al. 2006; Castell et al. 2008). The land-sea breeze cycle can drive pollutant recirculation for prolonged periods and contribute to ozone formation via both local and regional sources. Local $\mathrm{NO}_{x}$ emissions are considered to have a major role in ozone formation near the surface, while longer-range transport is more relevant at higher levels (Richards et al. 2013). Emissions of biogenic volatile organic compounds (BVOC) also impact ozone concentration over the Mediterranean Basin (Liakakou et al. 2007) and may increase summertime daily maxima by $5-10$ ppbv at different locations (Thunis and Cuvelier 2000; Curci et al. 2009). Shipborne measurements showed high ozone levels over the open sea during summer anticyclonic conditions: in particular, ozone concentration over the southeastern Tyrrhenian Sea was found to be driven by the presence of photochemically "aged" air masses containing ozone precursors emitted in the Rome and Naples areas (Velchev et al. 2011). The influence of sea-breeze circulation on the evolution of ozone abundance has also been described in other areas of the world (see, e.g., McKendry and Lundgren 2000; Cheng 2002; Sills et al. 2011), showing similarities with the Mediterranean dynamics summarized here.

The Italian peninsula presents a peculiar condition within the Mediterranean because of the presence of the high Apennine mountain chain at moderate distance from the coast, favoring the development of breeze circulations on both its western and eastern coasts. Anthropogenic activities in the densely populated coastal areas cause an injection of precursors into recirculating air masses that may be already ozone rich. This atmospheric dynamic is considered one of the reasons why the European Union (EU) limit for the protection of human health and vegetation (European Union 2008) is not attained in Italy (European Environment Agency 2015).

The relationships between summer circulation and ozone production have been studied in different areas of southern Italy on the basis of surface observations (Ciccioli et al. 1987; Mangia et al. 2010; Schipa et al. 2009; Schürmann et al. 2009), while no investigation was based on upper-air observations within the atmospheric boundary layer $(\mathrm{ABL})$ that can provide insights into topography and stratified circulation effects on coastal ozone dynamics.

Naples is the main conurbation of southern Italy and one of the largest urbanized areas on the Mediterranean shores, with more than three million inhabitants and a population density exceeding $10000 \mathrm{~km}^{-2}$ in some municipalities. Its vulnerability to ozone pollution is increased by intense agriculture spread over the inland plains and by forest areas extending farther inland over the Apennine chain and on Mount Vesuvius. Because of their geographical location and the prevalence of a sea-breeze wind regime during spring and summer, the agricultural and natural vegetation areas are exposed to the urban plume and can be affected by high ozone concentrations. On the other hand, forests may enhance ozone concentrations because of the photooxidation of BVOC emissions in the presence of $\mathrm{NO}_{x}$ (Fuentes et al. 2000; Atkinson and Arey 2003; Kemper Pacheco et al. 2014).

The Naples region has never been thoroughly investigated despite its vulnerability and its major role as source of ozone precursors; therefore, an assessment of the mechanisms regulating photochemical pollutants production and transport is desirable to identify possible measures to limit VOC and $\mathrm{NO}_{x}$ emissions and reduce human and ecosystems' exposure. This study analyses the ozone dynamics over the city of Naples and its surroundings. Surface and airborne meteorological and 
trace gases observations have been combined with regional and local-scale meteorological and air quality modeling to interpret the observed summer ozone cycles. Upper-air measurements were taken by the SkyArrow Environmental Research Aircraft (ERA) research aircraft (Gioli et al. 2006), which provided meteorological and air quality observations within the $\mathrm{ABL}$ and free troposphere, finally assessing the meteorological and photochemical processes controlling ozone formation, transport, and layering in urbanized coastal areas.

\section{Observations and model simulations}

This study was part of the Aria Salerno Napoli (Air in Salerno and Napoli district) (AriaSaNa) project, integrating regional ground-based and airborne measurements with state-of-the-art meteorological and air quality modeling. Within the project framework, a specific field campaign was planned to study the atmospheric circulation and emissions conditions favoring the occurrence of high ozone episodes.

\section{a. Airborne measurements}

The Sky Arrow ERA is a small, certified aircraft equipped with sensors to measure three-dimensional wind and turbulence at high frequency, together with gas concentrations and other atmospheric parameters (Gioli et al. 2006). The instrumentation deployed in this study included: a best aircraft turbulence (BAT) measuring $3 \mathrm{D}$ wind speed and air temperature at $50-\mathrm{Hz}$ frequency; an open-path infrared gas analyzer (IRGA; Licor 7500) to measure $\mathrm{H}_{2} \mathrm{O}$ and $\mathrm{CO}_{2}$ concentration at $50 \mathrm{~Hz}$; a laser altimeter (Riegl LD90-3) measuring aircraft above ground altitude; a UV analyzer (2B Technologies 202) to measure ozone concentration at $1 \mathrm{~Hz}$ with an accuracy of $\sim 1 \mathrm{ppb}$.

The campaign was planned on the basis of weather forecasts and performed on 15-16 July 2015, when a high pressure ridge of African origin affected the Mediterranean Basin and continental Europe (see Fig. S1 in the online supplemental material), causing high temperatures in different areas of the continent. Satellites showed clear-sky conditions over southern Italy and the western and central Mediterranean (see, e.g., the MODIS image in supplemental Fig. S1). The aircraft performed four flights during the morning and afternoon of 15 and 16 July 2015 , including both horizontal transects and vertical profiles, at a cruise speed of $\sim 150 \mathrm{~km} \mathrm{~h}^{-1}$. Transects were flown at an average height of $150 \mathrm{~m}$ AGL along a counterclockwise square track with side length of about $30 \mathrm{~km}$ enclosing Naples, its gulf, and Mount Vesuvius (Fig. 1). Four vertical upward and downward profiles (P1 to P4) were made at each of the track vertexes, from near

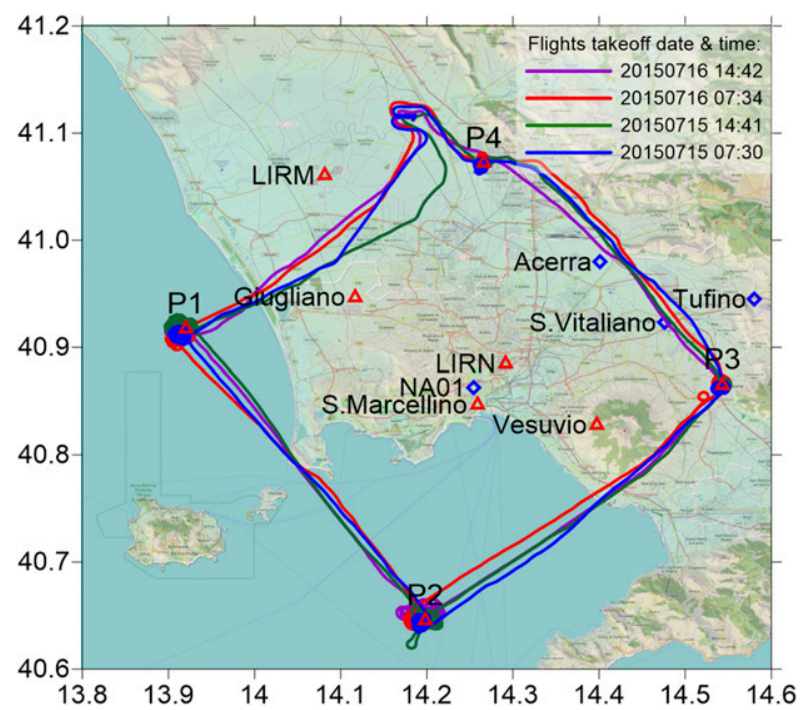

FIG. 1. Meteorological (red triangles) and air quality (blue diamonds) station locations, flight tracks, and location of the vertical profiles (P1-P4). Takeoff dates and local solar times are indicated in the legend. The axes show geographic coordinates.

ground up to a height of about $1500 \mathrm{~m}$ AGL, reaching the free troposphere between 0800 and 1700 local solar time (LST). P1 and P2 were located over the sea, while P3 and P4 were over land (Fig. 1).

The high-frequency observational data stream was then low-pass filtered to compute 30 -s average values of wind speed WS, wind direction WD, air temperature $T$, and ozone concentration, to be compared with corresponding model data associating each average measured value to the spatially and temporally closest model gridcell value. The value of $30 \mathrm{~s}$ to apply low-pass filtering was chosen as the best compromise to maintain high-resolution spatial information from flight data and to average high-frequency fluctuations associated with turbulent structures that are not resolved by numerical models (Gioli et al. 2004). The 30-s interval corresponds to an average horizontal flight path of about $1.3 \mathrm{~km}$, which is well comparable to model spatial gridcell size $(1 \mathrm{~km})$. Nevertheless, averaged aircraft measurements can still include temporal variability of atmospheric fields that, being in some circumstances related to nonstationary conditions, may be scarcely representative on model spatial and temporal scales.

\section{b. Ground-based meteorological and air quality observations}

While no information is routinely available on the vertical structure of the atmosphere, several ground-based meteorological and air quality stations are in operation in the study area (Fig. 1). Meteorological measurements were provided by the World Meteorological Organization 
TABLE 1. WRF-ARW physics options.

\begin{tabular}{ll}
\hline \hline \multicolumn{1}{c}{ WRF physics scheme } & \multicolumn{1}{c}{ Description } \\
\hline Microphysics & Single-moment 6-class scheme (ice, snow, and graupel processes) \\
Longwave radiation & Rapid Radiative Transfer Model \\
Shortwave radiation & Goddard shortwave \\
Cumulus parameterization & Kain-Fritsch scheme (deep and shallow convection) \\
Land surface & Noah land surface model \\
Surface layer & Eta similarity (based on Monin-Obukhov theory) \\
Planetary boundary layer & Mellor-Yamada-Janjić eta operational scheme \\
\hline
\end{tabular}

(WMO) stations of Napoli Capodichino [International Civil Aviation Organization (ICAO) code LIRN] and Grazzanise (ICAO code LIRM) airports. Further surface micrometeorological measurements were made at the San Marcellino site, at roof level in Naples city center $\left(40.8473^{\circ} \mathrm{N}, 14.2578^{\circ} \mathrm{E}\right)$, and at the northwestern periurban site of Giugliano $\left(40.9471^{\circ} \mathrm{N}\right.$, $\left.14.1171^{\circ} \mathrm{E}\right)$, which were both equipped with sonic anemometers.

The Naples conurbation air quality is monitored by the Regional Environmental Protection Agency of Campania Region (http://www.arpacampania.it/) measuring concentrations of pollutants regulated by the European air quality directives (European Union 2008). Routinely available measurements were integrated by supplementary air quality stations located at the San Marcellino site and at the Vesuvius Observatory (http:// www.ov.ingv.it; $\left.40.8279^{\circ} \mathrm{N} ; 14.3973^{\circ} \mathrm{E}\right)$.

\section{c. Meteorological and air quality models}

The AriaSaNa air quality forecast system for Naples city and the surrounding Campania region is based on the Flexible Air Quality Regional Model (FARM) chemical transport model (Silibello et al. 2008; Mircea et al. 2014) coupled with the Weather Research and Forecasting (WRF) Model (Skamarock et al. 2008). Pollutant emissions were modeled starting from the national emission inventory (Taurino et al. 2018), disaggregated at municipal level through activity-based proxies and supplemented by local information concerning industries and road and maritime traffic. WRF simulations were driven by the NOAA/NCEP GFS global-scale meteorological forecast, downloaded with $0.5^{\circ}$ grid spacing every $6 \mathrm{~h}$. Air quality boundary conditions were provided by the QualeAria air quality forecast system (Kukkonen et al. 2012; http://www.qualearia.it/), which uses the air quality model FARM and runs at European and national scale driven by the Copernicus Atmosphere Monitoring Service (CAMS) global air quality forecast (https:// atmosphere.copernicus.eu/). The physics schemes used by the WRF-ARW (version 3.5.1) forecast are summarized in Table 1. FARM gas phase chemistry implements the Statewide Air Pollution Research Center, version 1999 (SAPRC-99), model (Carter 2000).

The modeling system was configured to provide highresolution results on a target domain that encompasses all the measurement flight tracks, covering the central Campania region that includes all the major cities, the whole inland plains area, and a large percentage of the region's population (Fig. 2). Both WRF and FARM use two-way nesting. WRF was configured with four nested domains (Table 2), from continental scale down to the local target area, using a grid spacing of $3 \mathrm{~km}$ in the third domain, covering the whole Campania region, and of $1 \mathrm{~km}$ in the innermost fourth domain. FARM used two nested domains covering Campania and the target area with grid spacings of 4 and $1 \mathrm{~km}$, respectively. Model results were stored at hourly frequency. Surface values and vertical profiles of meteorological variables and pollutants concentrations were extracted at the surface stations and at aircraft profile locations, by selecting the nearest available time frame and applying bilinear interpolation among the four surrounding grid points on each model level.

Backward trajectories have been computed using RIP4, a WRF postprocessor developed by the National Center for Atmospheric Research (NCAR) and by the University of Washington (Stoelinga 2009), which includes the capability to compute backward/forward trajectories from WRF simulation results.

\section{Atmospheric circulation over the Gulf of Naples}

Local atmospheric circulation during the campaign was characterized by the typical sea-land breeze cycle, as detected by the LIRN observation tower (Fig. 3). Seabreeze southerly winds were observed during the late morning and the central hours of the day, with maximum speed ranging from 4 to $6 \mathrm{~ms}^{-1}$. Beginning in the late afternoon the wind turned from westerly to northerly, assuming the local land-breeze direction with decreasing speed and reaching nearly calm conditions at night (Fig. 3a). These breeze circulation features are similar to 


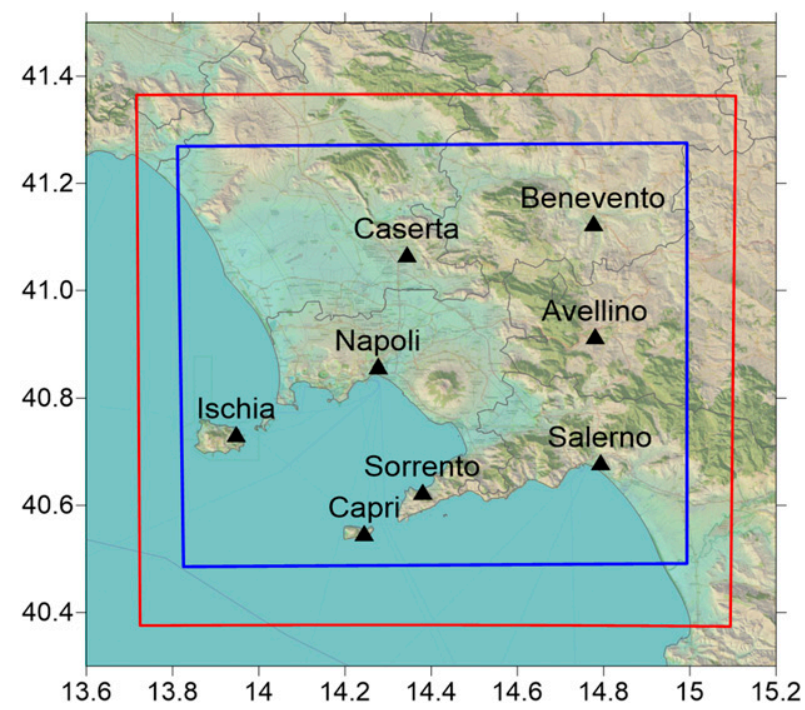

FIG. 2. Inner computational domains of the WRF (red) and FARM models (blue). Major cities and geographical locations are indicated by triangles.

those observed at other coastal sites (Millán et al. 2000; Adame et al. 2010; David and Nair 2011). Surface pressure showed a slowly increasing trend over the study period, evidencing subsidence due to the high pressure ridge persistence over the western Mediterranean (Fig. 3b). Air temperature showed a slight increasing trend in its daily maximum value, which exceeded $35^{\circ} \mathrm{C}$ on 17 July (Fig. 3c). Relative humidity had a general decreasing trend with short-term fluctuations (Fig. 3d). The surface winds were fairly well reproduced by the WRF Model simulation, which satisfactorily described the daily temperature cycles, decreasing relative humidity trend, and rising pressure (Figs. 3a-d). Surface energy and momentum fluxes measured with eddy covariance at the Giugliano rural site, northwest of Naples, were also correctly reproduced (Fig. 4), confirming a reliable reconstruction of near-surface weather conditions. The SkyArrow aircraft performed two flights a day to monitor circulation and air quality conditions during morning and afternoon hours. Weak winds with variable directions were measured during the 15 July morning flight (Fig. 5a), which lasted from 0730 to 1040 LST. WRF simulation confirmed the winds variability, but only partially reproduced aircraft measurements along the northwest and southeast legs, while relevant differences in wind direction were found along the southwest leg, over the sea, and the northeast leg, over the land (Fig. 5a). This result could be expected during the morning transition between land and seabreeze circulation, when local slope flows, residual land breezes, and transient phenomena can be dominant. The overall atmospheric circulation conditions predicted by WRF are depicted by the cross section at 180-m height AGL of the wind field computed at 0900 LST, showing large spatial variability over the domain (Fig. 5c).

Measured winds showed a well-developed sea-breeze circulation during the afternoon flight (from 1443 to 1739 LST) with prevailing west-southwest direction and an average speed of $5.9 \mathrm{~m} \mathrm{~s}^{-1}$ along the horizontal legs of the aircraft trajectory, flown at an average height of $157 \mathrm{~m}$ AGL (Fig. 5b). Local wind features were quite well reproduced by WRF, while significant discrepancies were only observed in the wake of Mount Vesuvius, where local orographic effects were dominant and strong turbulence conditions were recorded in the pilot report and confirmed by high-frequency wind fluctuation measurements. The turbulent kinetic energy in the Mount Vesuvius wake area showed an average value $40 \%$ larger than that measured along the overland portions of the horizontal flight legs. Horizontal wind spatial variability observed along the flight path can be interpreted from the analysis of the correspondent modeled wind field at $180 \mathrm{~m}$ AGL (Fig. 5d): the eastward wind rotation along the western leg of the flight is caused by the wake of Ischia Island, while the wind acceleration and convergence observed southeast and northeast of Mount Vesuvius can be attributed to topographic channeling and wake effect. The morning and afternoon flights on 16 July (not shown) confirmed a similar atmospheric circulation, with a slightly earlier development of the sea breeze and a prevailing southeast wind direction over the Gulf of Naples, which improved the agreement between observations and WRF simulations during the morning hours.

The measured vertical profiles, extending to a height of about $1600 \mathrm{~m}$ AGL, included the whole ABL and the first section of the adjacent free troposphere. $\mathrm{P} 4$ profiles

TABLE 2. WRF-ARW nested grid spacing.

\begin{tabular}{cccc}
\hline \hline Grid No. & Horizontal grid spacing $(\mathrm{km})$ & Vertical level No. & Cumulus parameterization \\
\hline 1 & 45 & 41 & Kain-Fritsch scheme \\
2 & 9 & 41 & Kain-Fritsch scheme \\
3 & 3 & 41 & None \\
4 & 1 & 41 & None \\
\hline
\end{tabular}



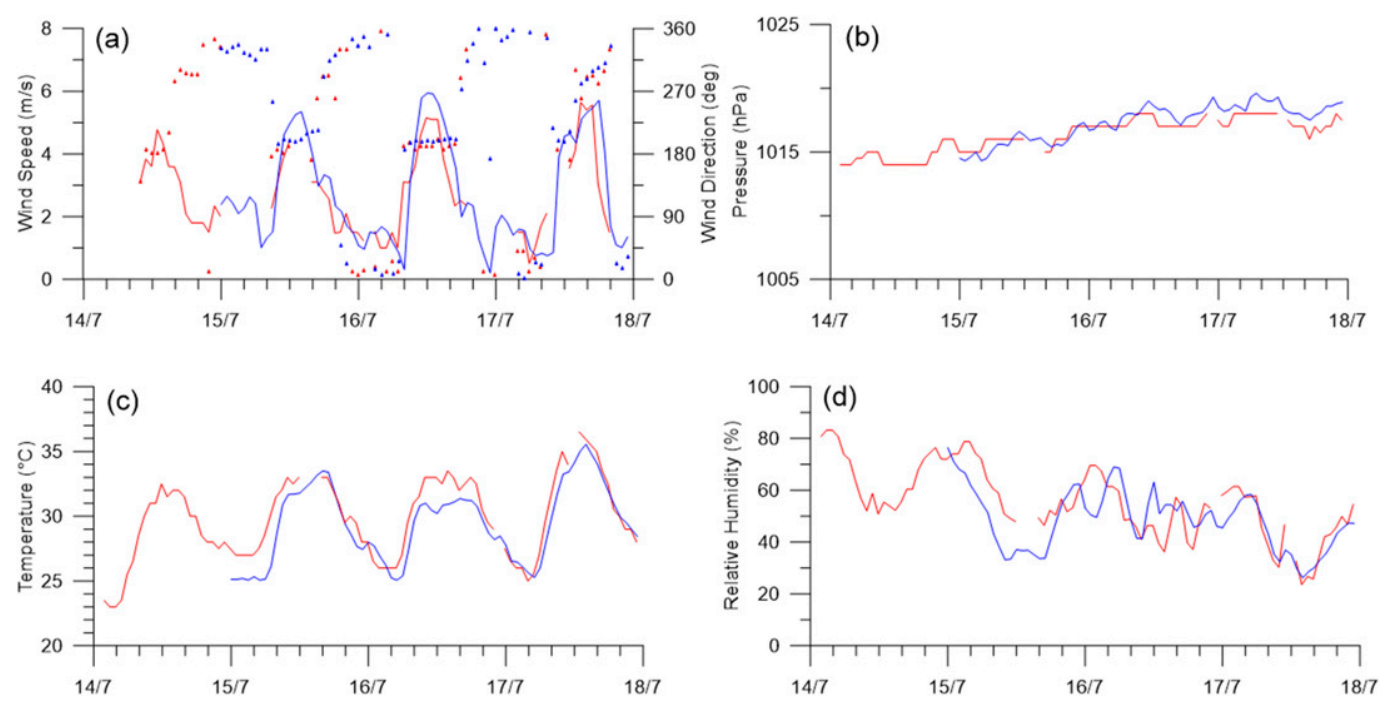

FIG. 3. Napoli Capodichino (LIRN) meteorological observations (red) and WRF simulation results (blue): (a) wind speed and direction, (b) sea level pressure, (c) air temperature, and (d) relative humidity.

(Fig. 6) are particularly interesting because of their location (Fig. 1), which is representative of the sea-breeze development and penetration over the inland plains area where high ozone concentrations are often recorded. The 15 July morning profile was measured from 1007 to 1033 LST, when a convective ABL is usually already well developed in summer fair-weather conditions. Both measured and modeled potential temperature profiles showed an adiabatic lapse rate up to 800-1000 m (Fig. 6c). The ABL depth has been evaluated applying the Sorensen (1998) method, as the height where the bulk Richardson number grows above a critical threshold value set to 0.25 . This approach has been applied to both measured and modeled profiles for consistency. The ABL depth computed from WRF results at this location was $735 \mathrm{~m}$ at 1000 LST, with an underestimation of about $9 \%$ with respect to the value of $808 \mathrm{~m}$ computed from airborne measurements (Fig. 6c). Very weak winds with wide direction variability were measured by the aircraft within the boundary layer, without a definable prevailing direction (Figs. 6a,b). Wind speed increased from 1 to $2 \mathrm{~m} \mathrm{~s}^{-1}$ to roughly $6 \mathrm{~m} \mathrm{~s}^{-1}$ from 800 to $1600 \mathrm{~m}$, with a welldefined east-northeast direction. The WRF simulation correctly reproduced such wind speed variation with height, and predicted the east-southeast direction in the
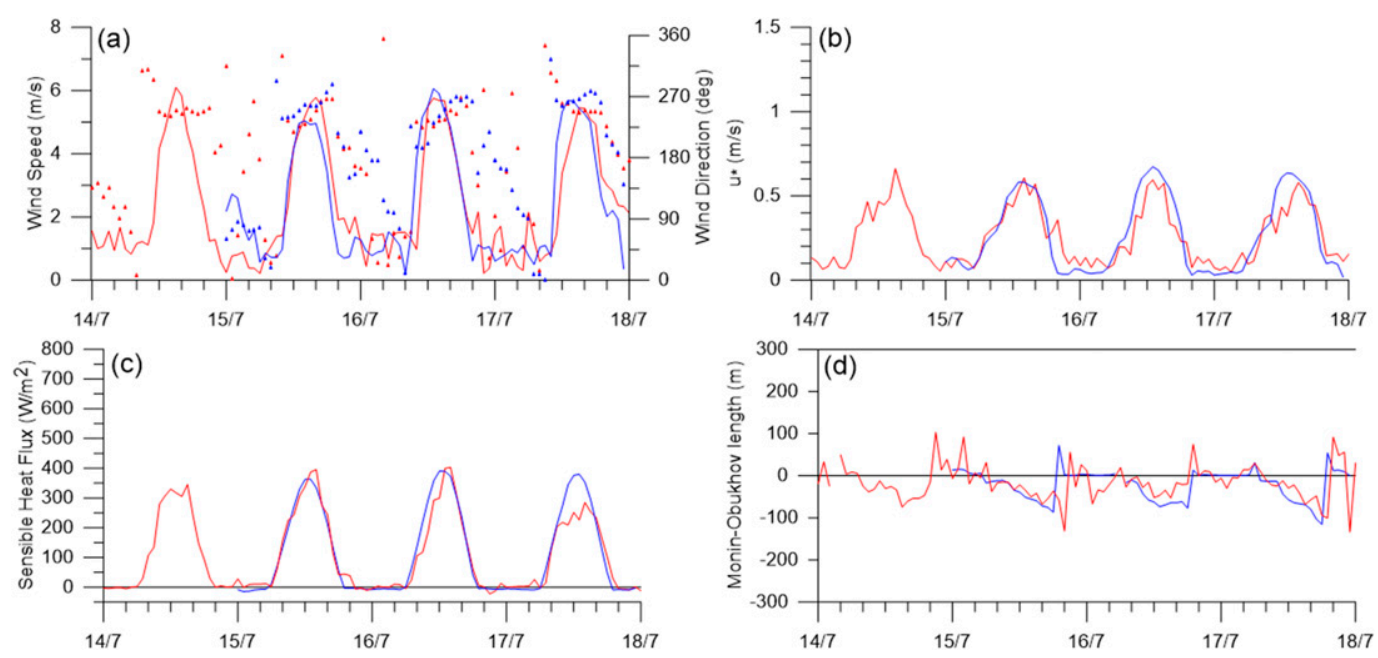

FIG. 4. Giugliano sonic anemometer observations (red) and WRF simulation results (blue): (a) wind speed and direction, (b) friction velocity, (c) sensible heat flux, and (d) Monin-Obukhov length. 

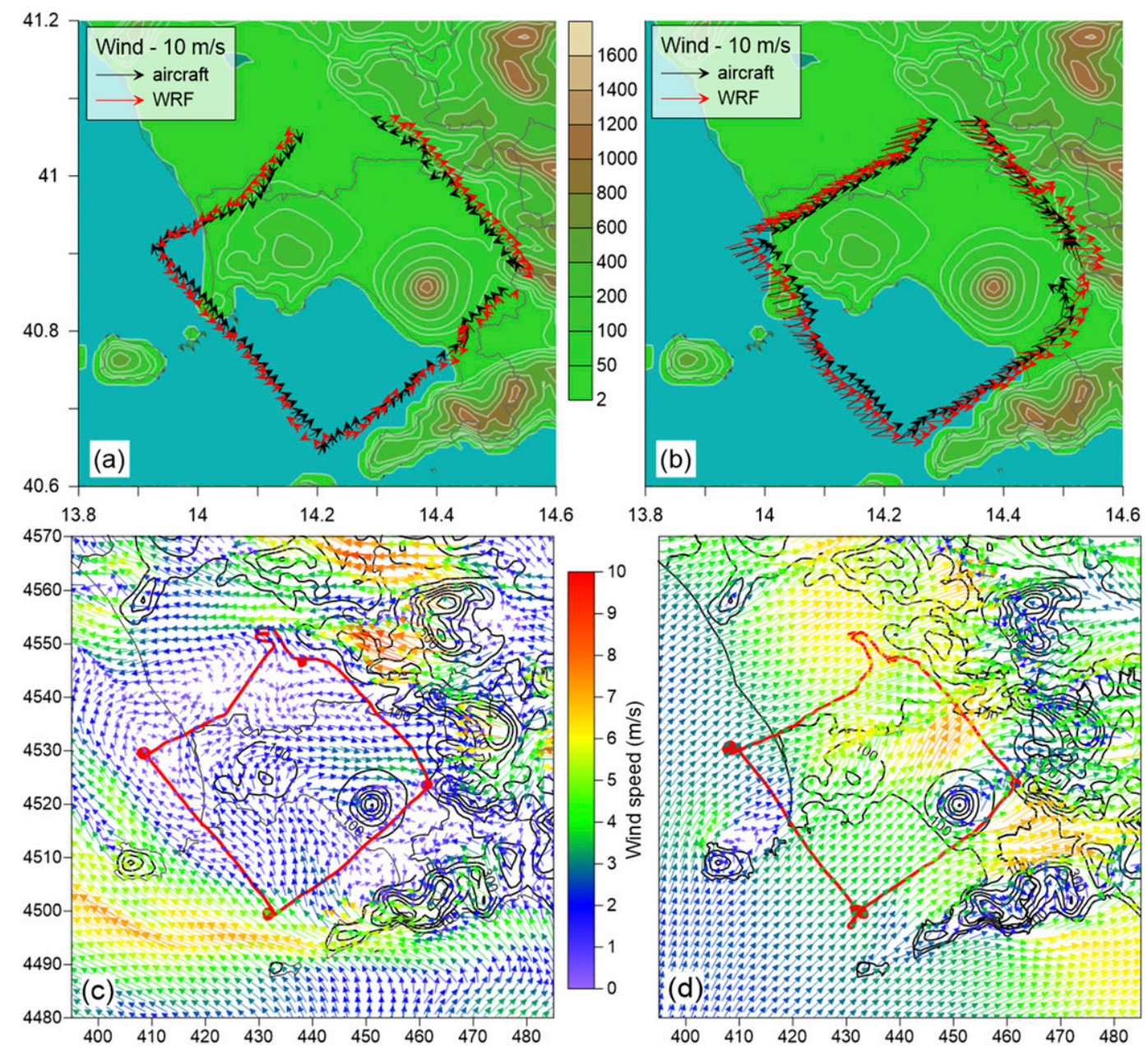

FIG. 5. Wind speed and direction measured by the aircraft during $15 \mathrm{Jul}$ (a) morning and (b) afternoon along the horizontal flight legs (black arrows) compared with WRF results (red arrows). Color scale refers to topography height. Wind fields predicted by WRF simulations at $180 \mathrm{~m} \mathrm{AGL}$ at (c) 0900 and (d) 1500 LST 15 Jul. The superimposed red line indicates the flight track.

upper layers and west-southwest direction below $400 \mathrm{~m}$, showing an earlier sea-breeze front penetration with respect to aircraft observations.

The 15 July afternoon flight measurements showed sea-breeze winds with west-west-southwest direction up to about $1000 \mathrm{~m}$, turning counterclockwise until becoming east at $1600 \mathrm{~m}$ (Figs. 6d,e). The wind speed was around $5 \mathrm{~m} \mathrm{~s}^{-1}$ in the lower $500 \mathrm{~m}$, decreasing at higher levels, up to about $1200 \mathrm{~m}$, where a layer characterized by relevant wind direction shear and slowly growing speed was observed up to $1600 \mathrm{~m}$ (Figs. 6d,e). The wind profile was well reproduced by WRF predictions, with a limited difference between 600 and $1200 \mathrm{~m}$, where the modeled direction was southwest, with a difference of about $45^{\circ}$ with respect to observations. It is worthwhile to note that the potential temperature profile showed an inversion at low elevation, between 400 and $600 \mathrm{~m}$, that was also reproduced by WRF, with an overestimation of about $1.2^{\circ} \mathrm{C}$ in the lower layers. The ABL depth of $440 \mathrm{~m}$ diagnosed from WRF results was substantially coincident with the value of $436 \mathrm{~m}$ estimated from measurements (Fig. 6f). As expected, the sea-breeze penetration over the inland plains caused a collapse of the ABL depth (Fig. 6f) with respect to the late morning values (Fig. 6c) because of the formation of a thermal internal boundary layer (Garratt 1990). This feature can be important to understanding ozone dynamics because of the possible trapping in the residual layer of pollutants dispersed vertically in the deeper boundary layer before the seabreeze front arrival (Millán et al. 2000).

P3 was strongly influenced by its geographical location, east of Mount Vesuvius, measuring a south-southeast wind with speed decreasing with height in the lower $500 \mathrm{~m}$ during both morning and afternoon flights (Figs. 7a,d). 

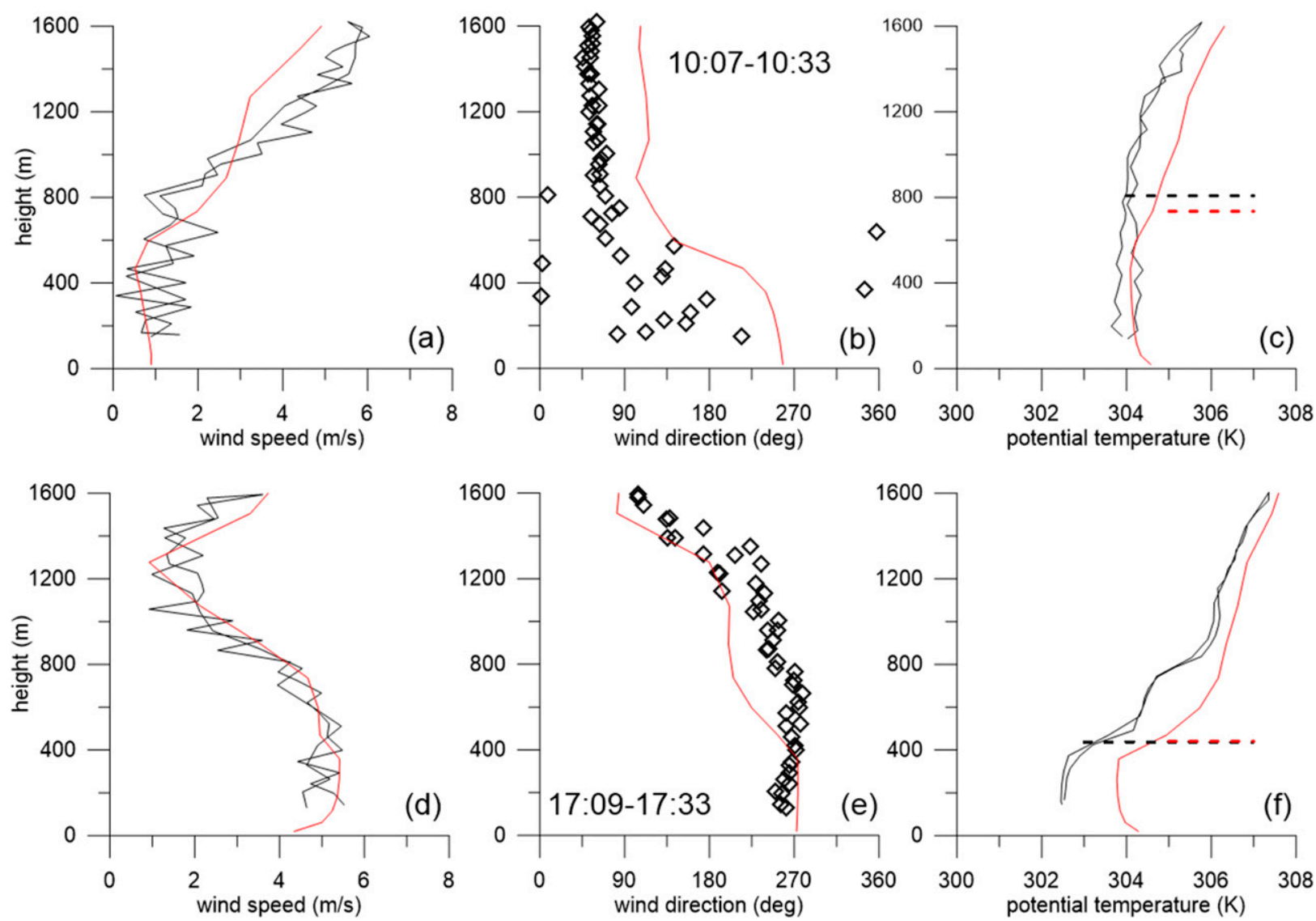

FIG. 6. Vertical profiles of (a),(d) wind speed,(b),(e) wind direction, and (c),(f) potential temperature measured by the aircraft on 15 Jul along its ascending and descending flight paths (black line and symbols) at location P4 compared with WRF results (red lines) extracted from the closest hourly time frame, at the same location. Morning flights are shown in (a)-(c) and afternoon flights are shown in (d)-(f); reference time intervals are indicated in (b) and (e). Dashed lines in (c) and (f) show the boundary layer height estimated from measured and computed meteorological profiles using the bulk Richardson number criterion.

Above this layer, the wind speed increased with height, blowing from the east during the morning and northwest during the afternoon. Potential temperature profiles (Figs. 7c,f) confirmed the presence of a mixing layer roughly $600 \mathrm{~m}$ deep as confirmed by the wind direction shear observed and correctly modeled at this height (Figs. 7b,e). The overall structure of the lower tropospheric flow and its time evolution were reconstructed by WRF, whose fields confirmed the influence of the Mount Vesuvius wake and flow channeling between the volcano and the Sorrento Peninsula on the sea-breeze development (Fig. 5). The differences between predicted and measured wind and temperature values were higher in the lower layers, where the mountain wake effect was too strong to be entirely reproduced at the model grid-space resolution. Near-surface values can be also influenced by the poor initialization of soil temperature and moisture. While local land-cover description has been improved by the introduction of the European Coordination of Information on the Environment (CORINE) land cover at 250-m resolution, no information was available to enhance the soil composition description.

All wind profiles measured on 15 July were characterized by directions between northeast and southeast in their upper layers (Figs. 6b,e and 7b,e), with minimum height of the easterly flow depending on location and time of day and ranging between 800 and $1400 \mathrm{~m}$. Model simulations confirmed this wind direction pattern up to about $3000 \mathrm{~m}$. This upper airflow behaves as a return current, potentially transporting pollutants seaward in the upper layers. The height of this layer is also compatible with return current observations made in other locations (see, e.g., Tijm et al. 1999; Millán et al. 2000).

\section{Ozone production and distribution}

Surface ozone observations were compared with the air quality model results (Fig. 8): a general increase of 

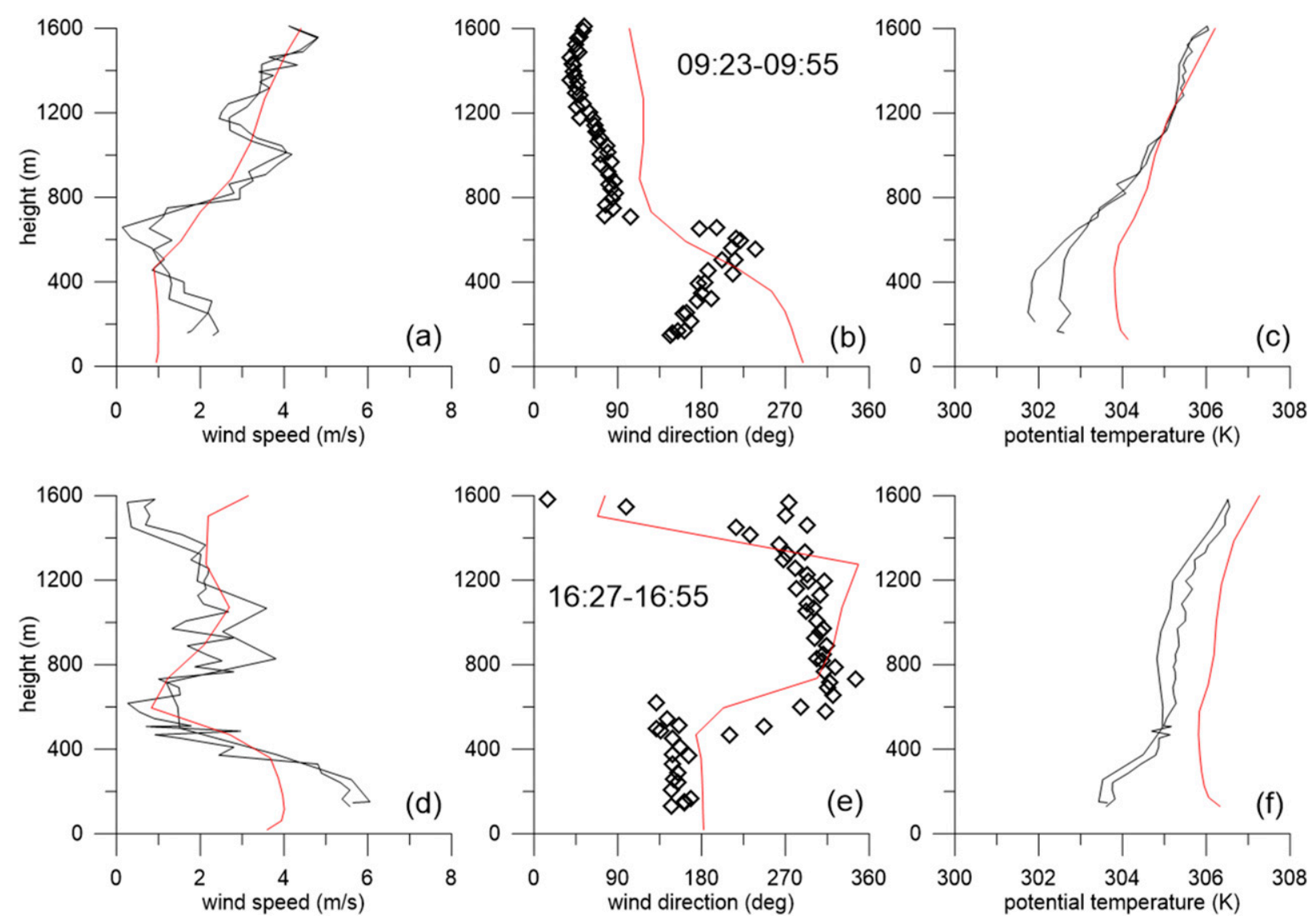

FIG. 7. As in Fig. 6, but for location P3.

daily maximum values can be observed moving from Naples near-coast city stations (San Marcellino and NA01; Fig. 1) to the inland plains area at increasing distance from the coast (Acerra, San Vitaliano, and Tufino; Fig. 1). Measurements in Naples were fairly well reproduced by FARM simulations (Figs. 8a,b), with a tendency to overestimate daily maxima and a correct reproduction of nighttime concentration levels, which confirms a correct reproduction of $\mathrm{NO}_{x}$ emissions driving nightly titration effect. The short-term time variability of measured concentration at San Marcellino and its relatively low daily maximum value (Fig. 8a) can be explained by the position of the station at roof level, about $500 \mathrm{~m}$ from the port, which exposes it to the plumes of large cargo and cruise ships. The model result verification at the urban background station NA01 is limited by missing observations during the experimental campaign (Fig. 8b). The ozone concentration and its time variability were correctly reproduced by the model at the Mount Vesuvius station (Fig. 8c) located at $608 \mathrm{~m}$ MSL on the southwestern slopes of the volcano (Fig. 1), where local anthropogenic emissions are scarce, as confirmed by the limited daily modulation of ozone concentration and elevated minimum nighttime values. The good performance of the modeling system at this background station confirms the effective reproduction of the atmospheric circulation over the studied area. The inland stations showed a relevant spatial variability of ozone concentrations (Figs. 8d-f), reflecting the complex land use that includes scattered urban areas, major motorways, and industrial sites within a landscape that is mainly agricultural. Moreover, during seabreeze flow the area is downwind of Naples, receiving plumes of pollutants emitted in the highly urbanized coastal strip. The model simulations were able to describe part of the variability observed among the inland stations (e.g., variation of maximum values), while they showed difficulties in reproducing nighttime ozone concentrations, which were generally overestimated. This behavior indicates that present knowledge of emissions in the Naples hinterland is insufficient to support a complete reconstruction of events controlled by local emissions like titration during nightly stagnation conditions. 

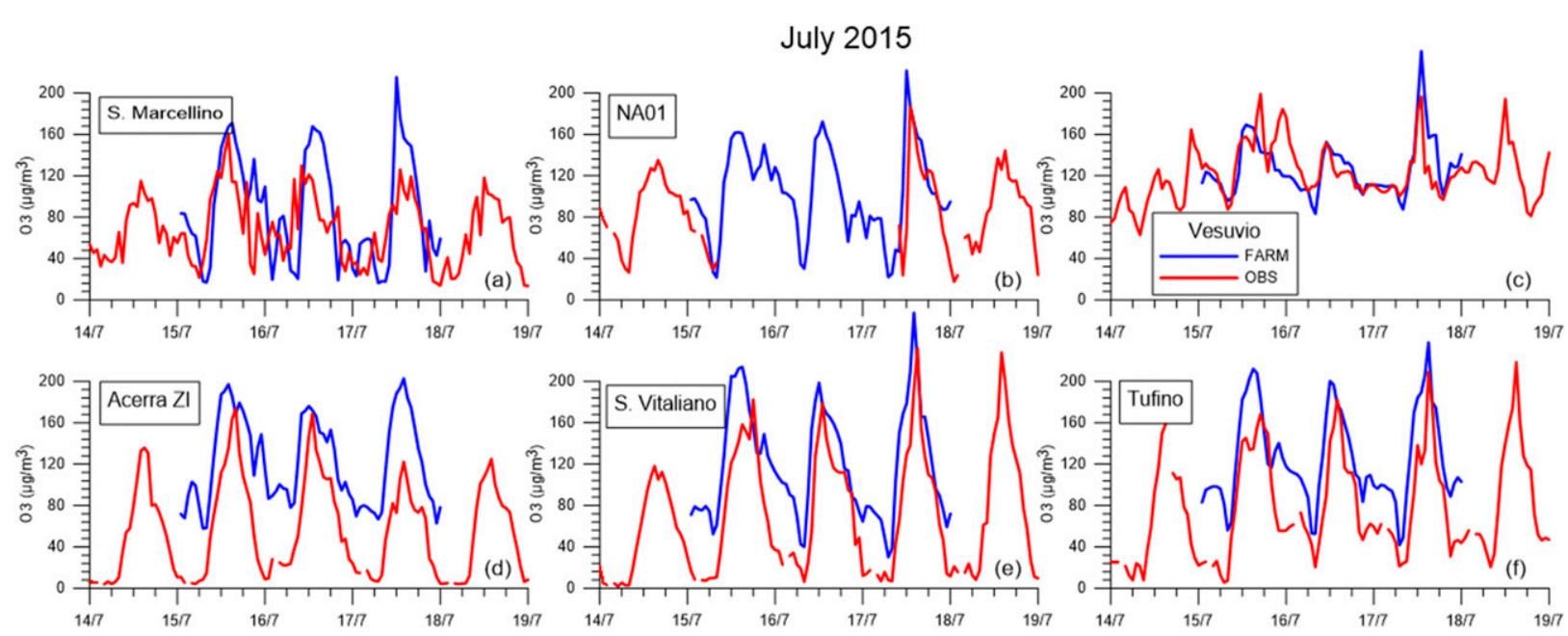

FIG. 8. Ozone concentrations measured (red) and computed by the FARM model (blue) at the monitoring stations of (a) San Marcellino and (b) NA01 located in Naples city; (c) on Mount Vesuvius; and in (d) Acerra, (e) San Vitaliano, and (f) Tufino on the inland plains.

Aircraft flights allowed to analyze ozone space and time variability over the Gulf of Naples and the inland plains area. The morning flight showed minimum ozone concentrations along the northwest leg (Fig. 9a), while the aircraft was flying over land before 0800 LST in nearly calm wind conditions (Fig. 5a). At this time of the day, during the transition between land and sea-breeze circulation conditions, titration due to local $\mathrm{NO}_{x}$ emissions can still be dominant. Concentrations grew to $100-140 \mu \mathrm{g} \mathrm{m}^{-3}$ over the sea (Fig. 9a), with a sharp increase as soon as the shoreline was crossed. Highest overland concentrations were recorded along the eastern portion of the trajectory, over the area northeast of Mount Vesuvius, with values up to $170 \mu \mathrm{g} \mathrm{m}^{-3}$.
Concentration values mostly over $140 \mu \mathrm{g} \mathrm{m}^{-3}$ were recorded along the northeastern horizontal leg (Fig. 9a).

An increase in ozone concentration levels was observed over the whole afternoon flight path (Fig. 9b) with respect to the morning values (Fig. 9a). Maximum values exceeding $200 \mu \mathrm{g} \mathrm{m}^{-3}$ were measured over the inland area northeast of Naples city center and north of Mount Vesuvius (Fig. 9b). It can also be noticed that concentration values recorded over the sea were higher north of Ischia Island than over the Gulf of Naples (Fig. 9b). This could be associated with the higher $\mathrm{NO}_{x}$ concentration detected over the Gulf of Naples (not shown) that can be attributed to the emissions of the intense shipping traffic during the tourist season, which
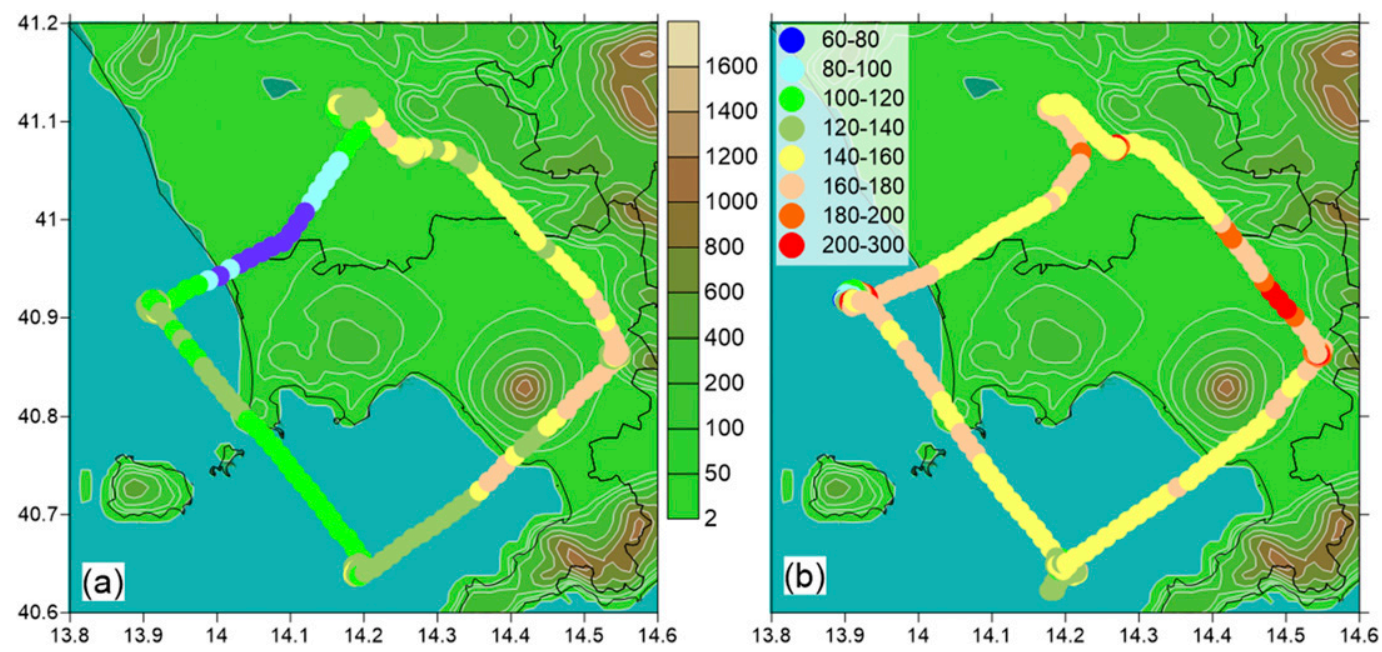

FIG. 9. Ozone concentrations $\left(\mu \mathrm{g} \mathrm{m}^{-3}\right)$ measured along the horizontal legs of the SkyArrow (a) morning and (b) afternoon flights on $15 \mathrm{Jul}$ 2015. Measurements were taken at cruise height of about $150 \mathrm{~m}$ AGL. Measured ozone values are superimposed on the topography height used by the models. 

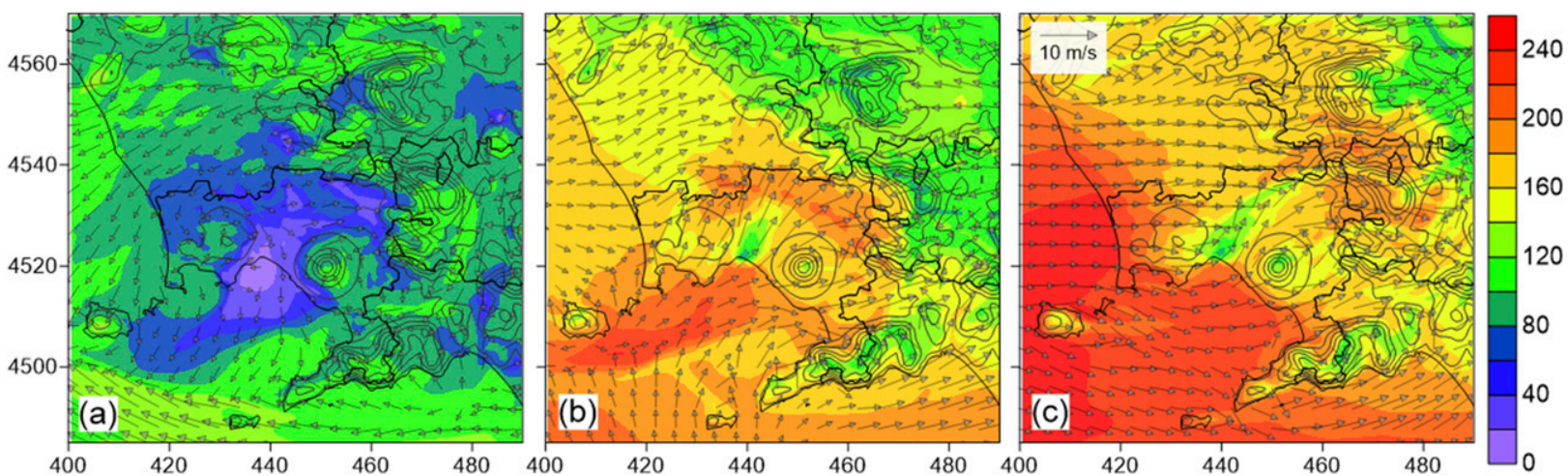

FIG. 10. Near-surface ozone concentrations $\left(\mu \mathrm{g} \mathrm{m}^{-3}\right)$ predicted by FARM model simulations for $15 \mathrm{Jul} 2015$ at (a) 0800 , (b) 1200 , and (c) 1700 LST. Wind field at 10-m height is represented by gray arrows.

involves both local ferries to the islands and large cruise and cargo ships.

The analysis of model concentration fields allowed us to identify the main ozone production area and its transport pathways (Fig. 10). During the morning, the atmospheric flow was dominated by weak land-breeze conditions transporting pollutants from the coastal area to the sea (Fig. 10a). The urban area of Naples, the inland plains, and a portion of the gulf facing the main port area were characterized by a minimum of ozone concentration due to the prevailing effect of titration at nighttime and in the early morning (Fig. 10a). From late morning to midday, the main areas of ozone production were the plains inland from Naples and between Mount Vesuvius and the Sorrento Peninsula (Fig. 10b). High concentrations were also predicted over the northern part of the Gulf, where ozone precursors have previously been advected by the land-breeze flow. Later in the afternoon, the sea-breeze penetration transported pollutants over the mountain slopes, locally reducing concentrations over the inland plains by dilution. Moreover, surface concentration fields showed an enlarged area influenced by the Naples plume that, being rich in $\mathrm{NO}_{x}$, caused a local reduction in ozone concentrations by a titration effect (Fig. 10c). At the same time, the coastal strip was reached by ozone advected from the sea and originating from an offshore reservoir, whose presence during sea breezes and summer high pressure conditions has been documented, for example, by Velchev et al. (2011).

The vertical ozone profiles measured by the aircraft over the sea (P1 and P2) during the morning hours (Figs. 11a,b) showed nearly constant concentration above $400 \mathrm{~m}$ with values close to $150 \mu \mathrm{g} \mathrm{m}^{-3}$. Below this height, concentration decreased toward the surface with values between 100 and $120 \mu \mathrm{g} \mathrm{m}^{-3}$. The FARM simulation reproduced the profile shape, with some underestimation of concentrations in the upper layers (Figs. 11a,b). Model results support the interpretation of the low value of near-surface ozone concentration as caused by $\mathrm{NO}_{x}$-rich and ozone-poor air masses originating from the urbanized coastal area and advected by land breezes during the night and early morning (Fig. 10a). The morning profile $\mathrm{P} 3$, measured over land (Fig. 11c), showed high ozone concentrations (150$175 \mu \mathrm{g} \mathrm{m}^{-3}$ ) within a layer about $600 \mathrm{~m}$ deep, reducing to values similar to those detected over the sea at higher vertical levels. The northeastern profile $\mathrm{P} 4$ over land showed ozone concentration slowly and regularly decreasing with height (Fig. 11d). The analysis of P4 meteorological measurements and model results evidenced the occurrence of a convective ABL with a depth of about $800 \mathrm{~m}$ (Fig. 6c). FARM simulations showed the tendency to underestimate P3 ozone values near the ground (Fig. 11c). This confirms the previous analysis of the time variation of modeled air pollutants showing a slight delay in the prediction of ozone growth, which is especially evident for P3. The comparison of model results with measurements in fact improved for all the profiles if a 1-h delayed time frame (e.g., 1100 LST instead of 1000 LST for P3) was extracted from model results (see dashed lines in Figs. 11a-d). Wind, surface energy, and momentum fluxes (Figs. $3 c$ and $4 a-c$ ) do not show any delay, while a slight time shift is observed in the daily growth of temperature in the urban environment (Fig. 3c). A possible cause of the ozone concentration growth delay can be the emissions time modulation, which is based on statistical analyses of anthropogenic activities and cannot guarantee an accurate reconstruction of the actual emissions time variability during a specific day.

The afternoon ozone profiles showed peculiar features. An increase of concentration in the lower $400 \mathrm{~m}$ was detected from the comparison of morning and afternoon profiles over water (P1 and P2; Figs. 11a,b,e,f), that was overestimated by the model (Figs. 11e,f). This discrepancy can be partially attributed to the western 

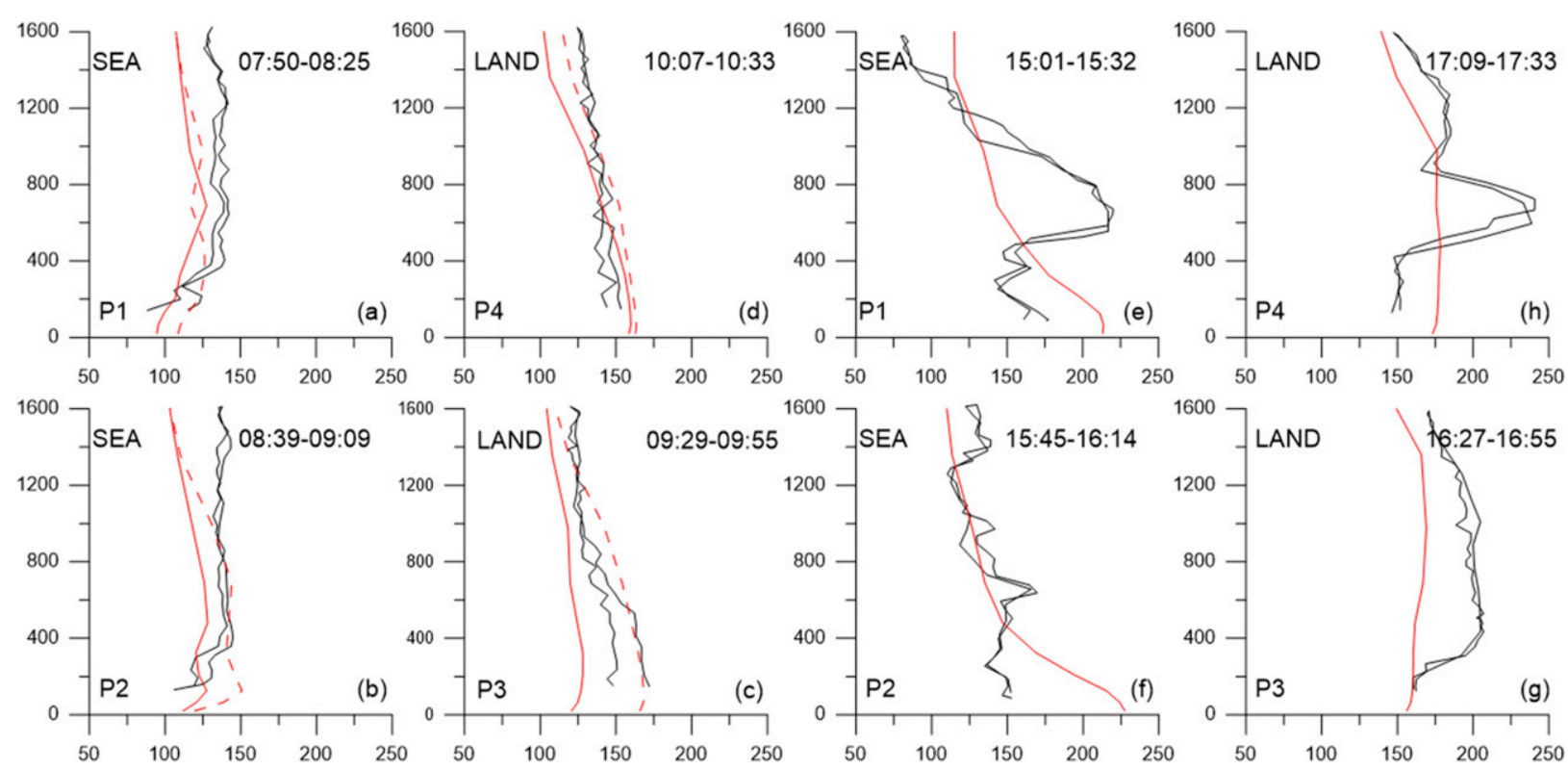

FIG. 11. Vertical profiles of ozone concentration $\left(\mu \mathrm{g} \mathrm{m}^{-3}\right)$ measured by the aircraft along its ascending and descending flight paths (black lines) at locations (a),(e) P1, (b),(f) P2, (c),(g) P3, and (d),(h) P4 during the morning [in (a)-(d)] and afternoon [in (e)-(h)] flights on $15 \mathrm{Jul}$ 2015. Start and end times of the ascending and descending aircraft flight paths are indicated for each profile. FARM results extracted at the same location are reported for the closest hourly time frame (red solid lines) and with 1-h delay (red dashed lines, for the morning flight only).

boundary conditions, provided by the continental-scale model, injecting ozone-rich air masses that were advected onshore by the southwesterly breeze (Fig. 10c). The two northern profiles ( $\mathrm{P} 1$ and $\mathrm{P} 4$ ) showed an ozone-rich layer between 400 and $1000 \mathrm{~m}$ (Figs. 11e,h), with concentrations higher than at the surface and maxima located around $600 \mathrm{~m}$. This pattern was neither reproduced by the model nor repeated on the second day of measurements, when ozone concentration was decreasing with height and nearly constant within the mixing layer (see supplemental material Fig. S2e). The transient nature of the observed phenomenon and the relatively low altitude of the ozone-rich layer support the hypothesis that it is caused by local recirculation rather than subsidence associated with the high pressure system over the Mediterranean (Millán et al. 2000, 2002; Richards et al. 2013). The ozone-rich layer observed over land (P4; Fig. 11h) is coincident with the residual layer located over the internal boundary layer (Fig. 6f), where pollutants have been injected during late morning, before the arrival of the breeze front, and could then remain trapped after the internal boundary layer development. During local recirculation events, a limited difference in predicted wind direction was probably the reason of the mismatch between modeled and measured profiles.

The possible origin of such ozone-rich layer was further investigated with the help of back-trajectories computed using RIP4 (Stoelinga 2009) from WRF wind fields on the third computational domain covering the whole Campania region with 3-km horizontal grid spacing. Trajectories arriving at $\mathrm{P} 1$, with vertical positions ranging from 356 to $734 \mathrm{~m}$, have been computed on both 15 and 16 July at 1500 LST to investigate the origin of air masses possibly carrying the elevated ozone-rich layer. The trajectories showed that airmass recirculation was more pronounced on 15 July (Fig. 12a) than on the following day (Fig. 12b). Trajectories reaching P1 during the afternoon westerly flow actually originated over land and traveled across some potentially ozone-rich layers over the Gulfs of Naples and Salerno (Fig. 12a). They can therefore confirm the hypothesis of local recirculation origin of the elevated concentration maxima. On 16 July the air masses arriving at P1 during the afternoon started over the open sea at the southern boundary of the computational domain (Fig. 12b), transporting background offshore concentrations that did not include any elevated maximum. Elevated ozone reservoir layers were observed by Lin et al. $(2007,2010)$ during sea-breeze circulation in Taiwan; however, the different climatic and circulation features, together with the presence of the Naples conurbation along the coastline, make it difficult to establish reliable similarities with the Mediterranean episode we analyzed.

The aircraft vertical profiles did not extend high enough to clearly detect pollutants transport toward the sea caused by the sea-breeze return current. 

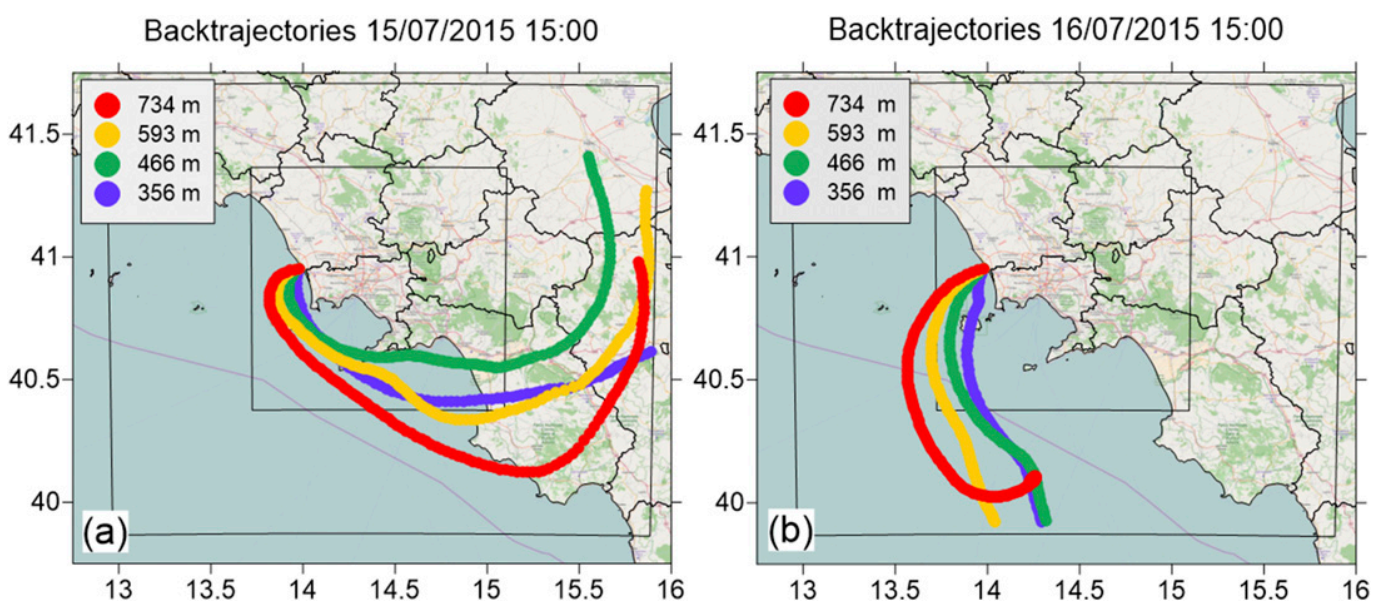

FIG. 12. Back trajectories arriving at profile P1 location from 356 to $734 \mathrm{~m}$ MSL at 1500 LST on (a) 15 Jul 2015 and (b) $16 \mathrm{Jul} 2015$. Color indicates trajectory height at the arrival point. Trajectories are followed for $24 \mathrm{~h}$ travel time.

Nonetheless, all meteorological profiles measured easterly winds at the upper levels, that is, over about $1400 \mathrm{~m}$, during the whole day (Figs. 6 and 7). WRF simulations showed easterly currents up to about $3000 \mathrm{~m}$, with maximum intensities around $2000 \mathrm{~m}$. Figure 13 shows a vertical cross section of ozone concentration computed by FARM along the northwestern transect of the flight track on $15 \mathrm{July}$ at 1800 . The concentration pattern suggests seaward transport of ozone with maximum values between 1000 and $2000 \mathrm{~m}$ (Fig. 13). The recirculation of pollutants was driven by the vertical dispersion of pollutants over the inland plains and by the vertical transport forced by the Apennine mountain range, which contributed to their injection into the high troposphere and finally to their transport seaward by the upper-air easterly current.

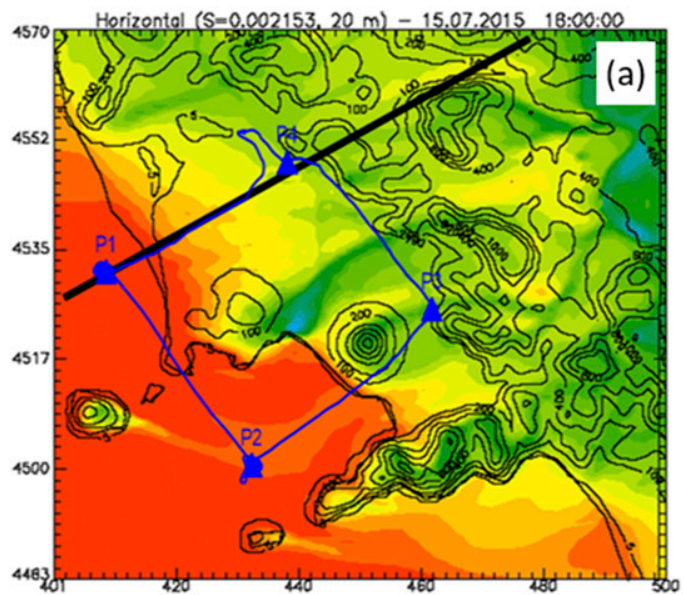

\section{Ozone mass balance over the Naples area}

Even in the presence of differences between model results and observations, the main features of the complex atmospheric circulation and ozone dynamics within the study area have been reconstructed, permitting us to use FARM model results to provide an estimation of the mass balance and the overall ozone production during sea-breeze daily cycles. The mass balance computation was performed within the inner model domain (Fig. 2) with a horizontal size of $99 \times 87 \mathrm{~km}^{2}$ and vertical depth of $10 \mathrm{~km}$. For each hour, the following integrated values were computed: total mass variation within the domain (TMV), net variation associated with chemical reactions production/removal (Chemistry), dry deposition flux (DryDep), and net flux through the lateral and top

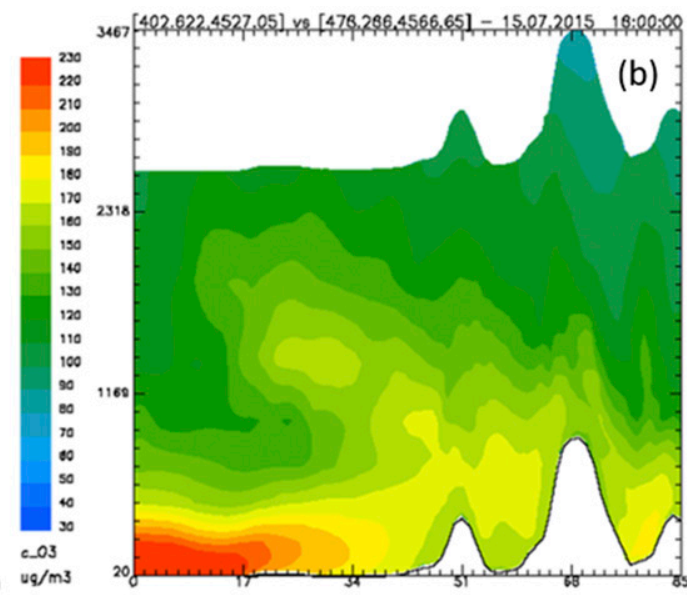

FIG. 13. Ozone concentration $\left(\mu \mathrm{g} \mathrm{m}^{-3}\right)$ in the (a) near-surface field and (b) vertical cross section across the shoreline. The concentration fields refer to 1800 LST 15 Jul 2015. The aircraft flight path (blue line) and vertical cross section position (black line) are superimposed on the horizontal cross section. 


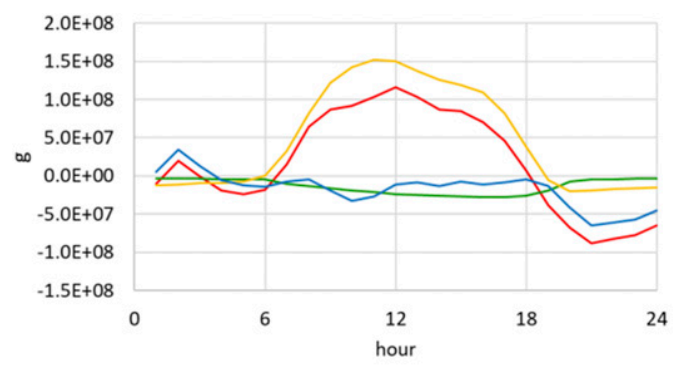

(a)

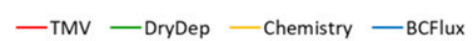

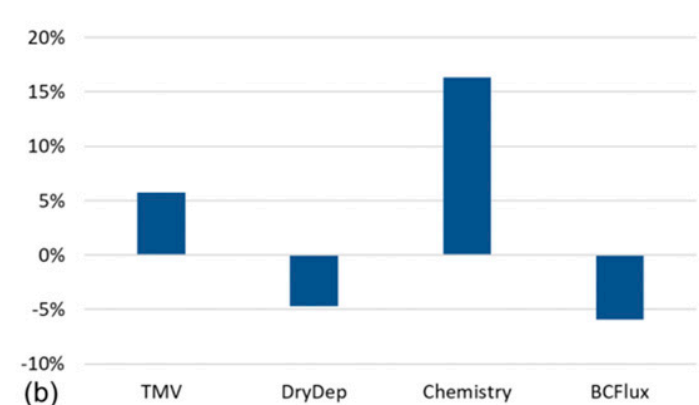

(b)

FIG. 14. Ozone mass balance within the FARM model inner computational domain. (a) Hourly and (b) daily integrated values for $15 \mathrm{Jul} 2015$. Hourly values are expressed in grams, while daily values are reported as fraction of the total mass within the computational domain.

boundaries (BFlux). Hourly and daily values of different contributions to the mass balance showed the expected daily cycle of atmospheric chemistry, producing ozone during the day and destroying it at night (Fig. 14a). The time variation of the total ozone mass reflected the same cycle, increasing during the day and decreasing at night. The dry deposition sink was more relevant during the day, when surface concentrations were higher and turbulence more intense. The local chemistry production, together with mesoscale circulation, caused prevailing ozone export conditions. The daily integrated values showed that ozone net production can be quantified as about $16 \%$ of the daily average mass contained within the computational domain volume (Fig. 14b). The net daily ozone mass gain resulting from chemical production, after subtraction of the deposition sink effect, was almost equally distributed between an increase of the total mass within the computational domain and the export through the boundaries, toward the nearby geographical areas. The contributions to the overall daily mass balance remained similar for the three days covered by model simulation (15-17 July 2015), causing an overall $23 \%$ increase of the ozone mass within the computational domain because of chemical production ( $45 \%$ of the initial mass) partially compensated by deposition and outflow.

\section{Discussion and conclusions}

The Naples area is considered one of the major anthropogenic sources of ozone precursors in the Mediterranean Basin. Its geographical location on the Italian peninsula near the high Apennine mountain chain favors the export of pollutants over the sea, where ozone accumulation has been detected from surface and satellite observations and from atmospheric modeling investigations. The integration of extensive measurements and model simulations allowed us to investigate the ozone production and transport during summer sea breeze and to identify the key role played by the inland plains areas, where agriculture is mixed with scattered urbanization, in controlling ozone and other secondary pollutants production. The advection of $\mathrm{NO}_{x}$ and other primary pollutants from Naples and its harbor area to the VOC-rich inland plains caused a relevant production of ozone in the area. Pollutants were vertically mixed in the convective boundary layer, up to a height of about $1 \mathrm{~km}$, until the sea-breeze front reached the inland plains around midday. A collapse of the boundary layer depth was then observed associated with the development of an internal boundary layer driven by the breeze penetration, creating a layered vertical structure of the lower atmosphere with high concentrations possibly trapped within the elevated residual layer. The sea-breeze penetration reduced surface ozone concentrations over the inland plains because of the joint effect of increased ventilation and advection of $\mathrm{NO}_{x}$-rich air masses, locally increasing the titration effect. Ozone was then transported eastward, over the Apennines, where BVOCs emitted by natural vegetation further triggered photochemical production. The mountain-breeze circulation reinforced the vertical transport of pollutants that were then advected westward toward the sea by the return currents above $1500 \mathrm{~m}$. The nightly land-breeze circulation carried ozone precursors from the densely inhabited coastal area to the sea within near-surface atmospheric layers. Nighttime titration conditions dominated over Naples city, the inland plains area, and the Gulf of Naples.

The observed complex flow and layered structure of the atmosphere is quite similar to that described by Millán et al. (2002) for eastern Spanish coasts, with differences induced by local topography that caused the intense ozone production over the inland plains located downwind of the city during sea breezes. 
Model simulations confirmed the role of the Naples conurbation as a regional source of ozone through a net production and direct export of ozone, together with its anthropogenic and biogenic precursors, as predicted by Velchev et al. (2011). Sea-breeze coastal circulation, together with the vertical atmospheric motion induced by the Apennine mountain chain, favors the recirculation within the coastal region and its transport toward the western Mediterranean, as clearly described by Millán et al. (1997).

Despite the relevant chemical ozone production occurring locally, the daily increase of the total ozone mass within the computational domain was less than $6 \%$ (Fig. 14b), with a slight increment of daily maximum concentration detectable in some of the surface observations. The local surface concentration is determined by a complex interaction of atmospheric flow and chemistry from the continental to the local scale. The regional background concentration of ozone and its precursors (entering the chemical transport model simulation through the initial and boundary conditions) have a dominant role in establishing local concentration levels, and especially their daily maxima. Different studies have already shown that local emission precursors control policies would have a limited or even negative effect on summer ozone episodes [see, e.g., Escudero et al. (2014) or Schipa et al. (2009) and Schürmann et al. (2009) for investigations in coastal locations of southern Italy]. Regardless, the coordinated reduction of pollutants' emission from the major conurbations located on or near the Mediterranean coasts is one of the main approaches to achieve an ozone concentration reduction at the regional scale and especially over the sea, where this pollutant accumulates during persistent high pressure conditions. The slight decreasing trend observed at background stations during recent years (Sicard et al. 2013; European Environment Agency 2015) is in fact an encouraging, albeit limited, sign of the possible effects of the EU air pollution control strategy. Efforts to reduce photochemical smog precursors' emissions should therefore be continued and extended from the continental to the global scale, taking into account the global emission trends (Miyazaki et al. 2017) and the negative effect of the expected climate warming over the Mediterranean (Giorgi and Lionello 2008; Gualdi et al. 2013; Sillmann et al. 2013).

\section{REFERENCES}

Adame, J. A., E. Serrano, J. P. Bolívar, and B. A. De la Morena, 2010: On the tropospheric ozone variations in a coastal area of southwestern Europe under a mesoscale circulation. J. Appl. Meteor. Climatol., 49, 748-759, https://doi.org/ 10.1175/2009JAMC2097.1.

Ancellet, G., and F. Ravetta, 2005: Analysis and validation of ozone variability observed by lidar during the
ESCOMPTE-2001 campaign. Atmos. Res., 74, 435-459, https://doi.org/10.1016/j.atmosres.2004.10.003.

Atkinson, R., 2000: Atmospheric chemistry of VOCs and $\mathrm{NO}_{x}$. Atmos. Environ., 34, 2063-2101, https://doi.org/ 10.1016/S1352-2310(99)00460-4

— , and J. Arey, 2003: Gas phase tropospheric chemistry of biogenic volatile organic compounds: A review. Atmos. Environ., 37 (Suppl. 2), 197-219, https://doi.org/10.1016/S1352-2310(03)00391-1.

Bach, H., and Coauthors, 2014: Services to assess the reasons for noncompliance of ozone target value set by Directive 2008/50/EC and potential for air quality improvements in relation to ozone pollution. ECORYS Final Rep., 50 pp., http://ec.europa.eu/ environment/air/pdf/Final_ozone_report.pdf.

Calfapietra, C., S. Fares, and F. Loreto, 2009: Volatile organic compounds from Italian vegetation and their interaction with ozone. Environ. Pollut., 157, 1478-1486, https://doi.org/ 10.1016/j.envpol.2008.09.048.

Carter, W. P. L., 2000: Documentation of the SAPRC-99 chemical mechanism for VOC reactivity assessment. California Air Resources Board Final Rep., Air Pollution Research Center and College of Engineering Center for Environmental Research and Technology, University of California, Riverside, CA, 230 pp., http://www.cert.ucr.edu/ carter/absts.htm\#saprc99.

Castell, N., E. Mantilla, and M. M. Millan, 2008: Analysis of tropospheric ozone concentration on a western Mediterranean site: Castellon (Spain). Environ. Monit. Assess., 136, 3-11, https://doi.org/10.1007/s10661-007-9723-1.

Cheng, W. L., 2002: Ozone distribution in coastal central Taiwan under sea-breeze conditions. Atmos. Environ., 36, 3445-3459, https://doi.org/10.1016/S1352-2310(02)00307-2.

Ciccioli, P., E. Brancaleoni, C. Di Paolo, A. Brachetti, and A. Cecinato, 1987: Daily trends of photochemical oxidants and their precursors in a suburban forested area. A useful approach for evaluating the relative contributions of natural and anthropogenic hydrocarbons to the photochemical smog formation in rural areas of Italy. Physico-Chemical Behaviour of Atmospheric Pollutants, G. Angeletti and G. Restelli, Eds., Springer, 551-559.

Curci, G., M. Beekmann, R. Vautard, G. Smiatek, R. Steinbrecher, J. Theloke, and R. Friedrich, 2009: Modelling study of the impact of isoprene and terpene biogenic emissions on European ozone levels. Atmos. Environ., 43, 1444-1455, https://doi.org/10.1016/j.atmosenv.2008.02.070.

David, L. M., and P. R. Nair, 2011: Diurnal and seasonal variability of surface ozone and $\mathrm{NO}_{x}$ at a tropical coastal site: Association with mesoscale and synoptic meteorological conditions. J. Geophys. Res., 116, D10303, https://doi.org/10.1029/2010JD015076.

Escudero, M., A. Lozano, J. Hierro, J. del Valle, and E. Mantilla, 2014: Urban influence on increasing ozone concentrations in a characteristic Mediterranean agglomeration. Atmos. Environ., 99, 322-332, https://doi.org/10.1016/j.atmosenv.2014.09.061.

European Environment Agency, 2015: Air quality in Europe-2015 report. EEA Rep. 5/2015, 64 pp., https:/www.eea.europa.eu/ publications/air-quality-in-europe-2015/at_download/file.

European Union, 2008: Directive 2008/50/EC of the European Parliament and of the Council of 21 May 2008 on ambient air quality and cleaner air for Europe. EU, 44 pp., http://eur-lex.europa.eu/legalcontent/EN/TXT/PDF/?uri=CELEX:32008L0050\&from=en.

Fuentes, J. D., and Coauthors, 2000: Biogenic hydrocarbons in the atmospheric boundary layer: A review. Bull. Amer. Meteor. Soc., 81, 1537-1575, https://doi.org/10.1175/1520-0477(2000) $081<1537$ :BHITAB $>2.3$. CO 2 .

Gangoiti, G., M. M. Millán, R. Salvador, and E. Mantilla, 2001: Long-range transport and re-circulation of pollutants in the 
western Mediterranean during the project Regional Cycles of Air Pollution in the West-Central Mediterranean Area. Atmos. Environ., 35, 6267-6276, https://doi.org/10.1016/ S1352-2310(01)00440-X.

Garratt, J. R., 1990: The internal boundary layer-A review. Bound.-Layer Meteor., 50, 171-203, https://doi.org/10.1007/ BF00120524.

Gioli, B., and Coauthors, 2004: Comparison between tower and aircraft-based eddy covariance fluxes in five European regions. Agric. For. Meteor., 127, 1-16, https://doi.org/10.1016/ j.agrformet.2004.08.004.

—_, F. Miglietta, F. P. Vaccari, A. Zaldei, and B. De Martino, 2006: The Sky Arrow ERA, an innovative airborne platform to monitor mass, momentum and energy exchange of ecosystems. Ann. Geophys., 49, 109-116, https://doi.org/10.4401/ag-3159.

Giorgi, F., and P. Lionello, 2008: Climate change projections for the Mediterranean region. Global Planet. Change, 63, 90-104, https://doi.org/10.1016/j.gloplacha.2007.09.005.

Gualdi, S., and Coauthors, 2013: The CIRCE simulations: Regional climate change projections with realistic representation of the Mediterranean Sea. Bull. Amer. Meteor. Soc., 94, 65-81, https://doi.org/10.1175/BAMS-D-11-00136.1.

Henschel, S., and G. Chan, 2013: Health risks of air pollution in Europe-HRAPIE project: New emerging risks to health from air pollution-Results from the survey of experts. World Health Organization Regional Office for Europe, 65 pp., http://www.euro.who.int/_data/assets/pdf_file/0017/ 234026/e96933.pdf?ua=1.

IPCC, 2007: Climate Change 2007: The Physical Science Basis. Cambridge University Press, 996 pp., https://www.ipcc.ch/pdf/ assessment-report/ar4/wg1/ar4_wg1_full_report.pdf.

_ 2014: Climate Change 2014: Synthesis Report. Cambridge University Press, 151 pp., https://www.ipcc.ch/pdf/assessment-report/ ar5/syr/SYR_AR5_FINAL_full.pdf.

Jiménez, P., J. Lelieveld, and J. M. Baldasano, 2006: Multiscale modeling of air pollutants dynamics in the northwestern Mediterranean basin during a typical summertime episode. J. Geophys. Res., 111, D18306, https://doi.org/10.1029/2005JD006516.

Kanakidou, M., and Coauthors, 2005: Organic aerosol and global climate modelling: A review. Atmos. Chem. Phys., 5, 10531123, https://doi.org/10.5194/acp-5-1053-2005.

Kemper Pacheco, C., S. Fares, and P. Ciccioli, 2014: A highly spatially resolved GIS-based model to assess the isoprenoid emissions from key Italian ecosystems. Atmos. Environ., 96, 50-60, https://doi.org/10.1016/j.atmosenv.2014.07.012.

Kukkonen, J., and Coauthors, 2012: A review of operational, regional-scale, chemical weather forecasting models in Europe. Atmos. Chem. Phys., 12, 1-87, https://doi.org/10.5194/ acp-12-1-2012.

Lelieveld, J., and Coauthors, 2002: Global air pollution crossroads over the Mediterranean. Science, 298, 794-799, https://doi.org/ 10.1126/science.1075457.

Liakakou, E., M. Vrekoussis, B. Bonsang, C. Donousis, M. Kanakidou, and N. Mihalopoulos, 2007: Isoprene above the eastern Mediterranean: Seasonal variation and contribution to the oxidation capacity of the atmosphere. Atmos. Environ., 41, 1002-1010, https:// doi.org/10.1016/j.atmosenv.2006.09.034.

Lin, C.-H., C.-H. Lai, Y.-L. Wu, P.-H. Lin, and H.-C. Lai, 2007: Impact of sea breeze air masses laden with ozone on inland surface ozone concentrations: A case study of the northern coast of Taiwan. J. Geophys. Res., 112, D14309, https://doi.org/ 10.1029/2006JD008123.
_ , Y.-L. Wu, and C.-H. Lai, 2010: Ozone reservoir layers in a coastal environment-A case study in southern Taiwan. Atmos. Chem. Phys., 10, 4439-4452, https://doi.org/10.5194/acp-10-4439-2010.

Lionello, P., F. Abrantes, M. Gacic, S. Planton, R. Trigo, and U. Ulbrich, 2014: The climate of the Mediterranean region: Research progress and climate change impacts. Reg. Environ. Change, 14, 1679, https://doi.org/10.1007/s10113-014-0666-0.

Mangia, C., I. Schipa, A. Tanzarella, D. Conte, G. P. Marra, M. M. Miglietta, and U. Rizza, 2010: Numerical study of the effect of sea breeze circulation on photochemical pollution over a highly industrialized peninsula. Meteor. Appl., 17, 19-31, https://doi.org/10.1002/met.147.

McKendry, I. G., and J. Lundgren, 2000: Tropospheric layering of ozone in regions of urbanized complex and/or coastal terrain: A review. Prog. Phys. Geogr., 24, 329-354, https://doi.org/ 10.1177/030913330002400302.

Millán, M. M., R. Salvador, E. Mantilla, and G. Kallos, 1997: Photooxidant dynamics in the Mediterranean basin in summer: Results from European research projects. J. Geophys. Res., 102, 8811-8823, https://doi.org/10.1029/96JD03610.

_- E. Mantilla, R. Salvador, A. Carratala, M. J. Sanz, L. Alonso, G. Gangoiti, and M. Navazo, 2000: Ozone cycles in the western Mediterranean basin: Interpretation of monitoring data in complex coastal terrain. J. Appl. Meteor. Climatol., 39, 487-508, https:// doi.org/10.1175/1520-0450(2000)039<0487:OCITWM>2.0.CO;2.

_- M. J. Sanz, R. Salvador, and E. Mantilla, 2002: Atmospheric dynamics and ozone cycles related to nitrogen deposition in the western Mediterranean. Environ. Pollut., 118, 167-186, https://doi.org/10.1016/S0269-7491(01)00311-6.

- and Coauthors, 2005: Climatic feedbacks and desertification: The Mediterranean model. J. Climate, 18, 684-701, https:// doi.org/10.1175/JCLI-3283.1.

Mircea, M., and Coauthors, 2014: Assessment of the AMSMINNI system capabilities to predict air quality over Italy for the calendar year 2005. Atmos. Environ., 84, 178-188, https://doi.org/10.1016/j.atmosenv.2013.11.006.

Miyazaki, K., H. Eskes, K. Sudo, K. F. Boersma, K. Bowman, and Y. Kanaya, 2017: Decadal changes in global surface $\mathrm{NO}_{x}$ emissions from multi-constituent satellite data assimilation. Atmos. Chem. Phys., 17, 807-837, https://doi.org/10.5194/acp-17-807-2017.

Paoletti, E., 2006: Impact of ozone on Mediterranean forests: A review. Environ. Pollut., 144, 463-474, https://doi.org/10.1016/ j.envpol.2005.12.051.

Parrish, D. D., and Coauthors, 2012: Long-term changes in lower tropospheric baseline ozone concentrations at northern mid-latitudes. Atmos. Chem. Phys., 12, 11 485-11 504, https:// doi.org/10.5194/acp-12-11485-2012.

Querol, X., and Coauthors, 2014: 2001-2012 trends on air quality in Spain. Sci. Total Environ., 490, 957-969, https://doi.org/ 10.1016/j.scitotenv.2014.05.074.

Richards, N. A. D., S. R. Arnold, M. P. Chipperfield, G. Miles, A. Rap, R. Siddans, S. A. Monks, and M. J. Hollaway, 2013: The Mediterranean summertime ozone maximum: Global emission sensitivities and radiative impacts. Atmos. Chem. Phys., 13, 2331-2345, https://doi.org/10.5194/acp-13-2331-2013.

Schipa, I., A. Tanzarella, and C. Mangia, 2009: Differences between weekend and weekday ozone levels over rural and urban sites in southern Italy. Environ. Monit. Assess., 156, 509-523, https://doi.org/10.1007/s10661-008-0501-5.

Schürmann, G. J., A. Algieri, I. M. Hedgecock, G. Manna, N. Pirrone, and F. Sprovieri, 2009: Modelling local and synoptic scale influences on ozone concentrations in a topo- 
graphically complex region of southern Italy. Atmos. Environ., 43, 4424-4434, https://doi.org/10.1016/j.atmosenv.2009.06.017.

Sicard, P., A. De Marco, F. Troussier, C. Renou, N. Vas, and E. Paoletti, 2013: Decrease in surface ozone concentrations at Mediterranean remote sites and increase in the cities. Atmos. Environ., 79, 705-715, https://doi.org/ 10.1016/j.atmosenv.2013.07.042.

Silibello, C., G. Calori, G. Brusasca, A. Giudici, E. Angelino, G. Fossati, E. Peroni, and E. Buganza, 2008: Modelling of PM10 concentrations over Milano urban area using two aerosol modules. Environ. Modell. Software, 23, 333-343, https://doi.org/10.1016/j.envsoft.2007.04.002.

Sillmann, J., V. V. Kharin, F. W. Zwiers, X. Zhang, and D. Bronaugh, 2013: Climate extremes indices in the CMIP5 multimodel ensemble: Part 2. Future climate projections. J. Geophys. Res. Atmos., 118, 2473-2493, https://doi.org/10.1002/jgrd.50188.

Sills, D. M. L., J. R. Brook, I. Levy, P. A. Makar, J. Zhang, and P. A. Taylor, 2011: Lake breezes in the southern Great Lakes region and their influence during BAQS-Met 2007. Atmos. Chem. Phys., 11, 7955-7973, https://doi.org/10.5194/acp-11-7955-2011.

Skamarock, W. C., and Coauthors, 2008: A description of the Advanced Research WRF version 3. NCAR Tech. Note NCAR/TN-475+STR, 113 pp., http://dx.doi.org/10.5065/ D68S4MVH.

Sorensen, J. H., 1998: Sensitivity of the DERMA long-range Gaussian dispersion model to meteorological input and diffusion parameters. Atmos. Environ., 32, 4195-4206, https:// doi.org/10.1016/S1352-2310(98)00178-2.

Stoelinga, M. T., 2009: A users' guide to RIP version 4.5: A program for visualizing mesoscale model output. University of
Washington, 82 pp., http://www2.mmm.ucar.edu/wrf/users/ docs/ripug.pdf.

Taurino, E. and Coauthors, 2018: Italian Emission Inventory 1990-2016 Informative Inventory Report 2018. Istituto Superiore per la Protezione e la Ricerca Ambientale Annual Rep., 195 pp., http://www.sinanet.isprambiente.it/it/sia-ispra/ serie-storiche-emissioni/informative-inventory-report/view.

Thunis, P., and C. Cuvelier, 2000: Impact of biogenic emissions on ozone formation in the Mediterranean area-A BEMA modelling study. Atmos. Environ., 34, 467-481, https://doi.org/ 10.1016/S1352-2310(99)00313-1.

Tijm, A. B. C., A. A. M. Holtslag, and A. J. Van Delden, 1999: Observations and modeling of the sea breeze with the return current. Mon. Wea. Rev., 127, 625-640, https://doi.org/10.1175/ 1520-0493(1999)127<0625:OAMOTS >2.0.CO;2.

Velchev, K., F. Cavalli, J. Hjorth, E. Marmer, E. Vignati, F. Dentener, and F. Raes, 2011: Ozone over the western Mediterranean Sea-Results from two years of shipborne measurements. Atmos. Chem. Phys., 11, 675-688, https://doi.org/ 10.5194/acp-11-675-2011.

WHO, 2013: Review of evidence on health aspects of air pollutionREVIHAAP project. World Health Organization Regional Office for Europe Tech Rep., 309 pp., http://www.euro.who.int/ __data/assets/pdf_file/0004/193108/REVIHAAP-Finaltechnical-report-final-version.pdf.

Ziemke, J. R., S. Chandra, G. J. Labow, P. K. Bhartia, L. Froidevaux, and J. C. Witte, 2011: A global climatology of tropospheric and stratospheric ozone derived from Aura OMI and MLS measurements. Atmos. Chem. Phys., 11, 9237-9251, https://doi.org/10.5194/acp-11-9237-2011. 